\title{
Antigenotoxic and anticytotoxic activity of Duguetia furfuracea in bacteria and mice
}

\author{
C.R. Silva, P.M. Vieira and L. Chen-Chen \\ Instituto de Ciências Biológicas, Universidade Federal de Goiás, \\ Goiânia, GO, Brasil \\ Corresponding author: L. Chen-Chen \\ E-mail: chenleego@yahoo.com.br \\ Genet. Mol. Res. 12 (3): 3718-3725 (2013) \\ Received January 17, 2013 \\ Accepted August 16, 2013 \\ Published September 19, 2013 \\ DOI http://dx.doi.org/10.4238/2013.September.19.2
}

Laboratório de Radiobiologia e Mutagênese, Departamento de Biologia Geral,

\begin{abstract}
Duguetia furfuracea (St. Hil.) Benth \& Hook f. (1862), popularly known as "sofre-do-rim-quem-quer" and "araticum-seco", is a shrub of the Annonaceae family that grows in several regions of Brazil. Infusions of its leaves and twigs are used in folk medicine to treat rheumatism and renal colic, whereas the seed powder is mixed with water to treat pediculosis. Studies on the plant have reported biological activities with cytotoxic, antitumoral, trypanocidal, leishmanicidal, antiplasmodial, and antiprotozoal effects. Our previous studies using a prophage $\lambda$ induction test (SOS-Inductest) and the micronucleus assay demonstrated that $D$. furfuracea lyophilized leaf extract (DFE) displayed cytotoxic but not genotoxic activity. In the present study, antigenotoxic and anticytotoxic activities of DFE were evaluated using SOS-Inductest and mouse bone marrow micronucleus tests. Our results showed that DFE decreased the induction of either prophage $\lambda$ ( $\mathrm{P}<0.05$; SOS-Inductest) or micronucleated polychromatic erythrocytes $(\mathrm{P}<0.05$; micronucleus test) at all doses, suggesting antigenotoxic activity in both tests. On assessing the anticytotoxic activity of DFE, a significant increase in the number of bacteria at lower doses $(\mathrm{P}<0.05)$ as well as a significant increase in the polychromatic and normochromatic erythrocyte ratio were observed $(\mathrm{P}<$
\end{abstract}


0.05), demonstrating the anticytotoxic activity of DFE. Thus, D. furfuracea displayed antigenotoxic and anticytotoxic activity in both assays.

Key words: Duguetia furfuracea; Antigenotoxicity; Anticytotoxicity; Micronucleus test; SOS-Inductest

\section{INTRODUCTION}

The plant kingdom is vast, and the extent of ancient uses of plants to treat various human ailments remains unknown. A considerable number of natural products are currently used in traditional medical systems in many countries to treat disease (Choi and Hwang, 2003; Alves dos Santos et al., 2008). The use of natural products and their active components to prevent or treat chronic disease is based primarily on epidemiological data and the traditional medicine practiced by a variety of ethnic groups (Resende et al., 2007). Thus, several recent studies dedicated to popular medicine have aimed to identify natural products with therapeutic properties (Ghazali et al., 2011).

Duguetia furfuracea (St. Hil.) Benth \& Hook f. (1862) is a shrub of the Annonaceae family that grows in several regions in Brazil (Rodrigues and Carvalho, 2001; Carollo et al., 2006a) where it is popularly known as sofre-do-rim-quem-quer and araticum-seco. In folk medicine, infusions of the leaves and twigs of this species are used to treat rheumatism and renal colic (Rodrigues and Carvalho, 2001). Duguetia furfuracea seed powder is also used to treat pediculosis (Silberbauer-Gottsberger, 1981/1982). Alkaloids and flavonoids have already been isolated from the aerial parts of Duguetia furfuracea and identified (Carollo et al., 2006a). Furthermore, many biological activities such as toxicity to mouse embryos (Toledo et al., 2006) and trypanocidal, antiplasmodial, and antiprotozoal properties (Fischer et al., 2004; Carollo et al., 2006a; de Mesquita et al., 2007) have been reported in this plant species.

Most traditional medicinal plants have never been subjected to the exhaustive toxicological tests required for modern pharmaceutical compounds. They are often assumed to be safe based on the long duration of their traditional use. However, research has shown that many plants used as food ingredients or in traditional medicine have in vitro mutagenic (Cardoso et al., 2006; Déciga-Campos et al., 2007; Mohd-Fuat et al., 2007) and antimutagenic (Park et al., 2004; Kilani et al., 2005; Bouhlel et al., 2007) properties. Therefore, investigations of the mutagenic or antimutagenic potentials of traditionally used medicinal plants constitute an important approach for the discovery of novel chemotherapeutic drugs and assurance of the safety of their continued use (Cherdshewasart et al., 2009; Ghazali et al., 2011).

Studies carried out by our team using the lysogenic induction test (SOS-Inductest) and mouse bone marrow micronucleus assay have demonstrated that Duguetia furfuracea lyophilized leaf extract (DFE) has cytotoxic but not genotoxic activity (Silva et al., 2012). In the present study, we investigated the antigenotoxic and anticytotoxic activity of DFE using these tools (Heddle, 1973; Moreau et al., 1976).

\section{MATERIAL AND METHODS}

\section{Plant material}

Samples of Duguetia furfuracea leaves were collected in the district of Itanhangá, munici- 
pality of Goiânia, in the state of Goiás, Brazil (16³4'23.92"S, 49 $\left.166^{\prime} 28.82^{\prime \prime} \mathrm{W}\right)$. The plant was identified by Prof. Heleno Dias Ferreira (Universidade Federal de Goiás), and a voucher specimen (No. 29975) was deposited in the Central Herbarium of the Universidade Federal de Goiás (Goiânia, Brazil). The leaves were dried at $40^{\circ} \mathrm{C}$ in a forced ventilation stove and ground in a fraction mill to a dry powder that was submitted to hot aqueous extraction $(85 \mathrm{~g} / 1000 \mathrm{~mL})$ and lyophilization. The lyophilized extract was stored at $-18^{\circ} \mathrm{C}$ until further use and dissolved in water for the tests.

\section{SOS-Inductest}

\section{Strains}

The SOS-Inductest tester strains WP2s( $\lambda$ ) (lysogenic strain) and RJF013 (indicator strain), derived from Escherichia coli, were supplied by the Laboratório de Radiobiologia Molecular Instituto de Biofísica Carlos Chagas Filho, Universidade Federal do Rio de Janeiro (Brazil).

\section{Prophage $\lambda$ induction}

SOS-Inductest experiments were performed according to the protocol reported by Moreau et al. (1976). WP2s $(\lambda)$, which contains a mutation in the gene $u v r A$ (da Fonseca et al., 1994), was grown on Luria-Bertani (LB) medium (1\% bacto tryptone, lot No. 9117660 , Difco, Sparks, MD, USA; 0.5\% bacto yeast extract, lot No. 1551325, Biobras, Montes Claros, Brazil; $1 \% \mathrm{NaCl}$, lot No. 87642, Vetec Química Fina Ltda, Duque de Caxias, Brazil) until the culture reached the exponential growth phase. At this point, $15 \mathrm{~mL}$ culture was centrifuged at $3000 \mathrm{x} g$ for $15 \mathrm{~min}$ and resuspended using the same volume of M9 buffer $\left(0.6 \% \mathrm{Na}_{2} \mathrm{HPO}_{4}\right.$, lot No. 19117, Dinâmica Química Contemporânea, São Paulo, Brazil; 0.3\% $\mathrm{KH}_{2} \mathrm{PO}_{4}$, lot No. 1644, Cinética Química Ltda., São Paulo, Brazil; $0.5 \%$ NaCl, lot No. 87642, Vetec; $1 \mathrm{~mL} 1 \mathrm{M}$ $\mathrm{MgSO}_{4}$, lot No. 871243, Vetec). Then, 1-mL aliquots of the bacterial culture were incubated with various doses of DFE $(1,2,5$, and $10 \mathrm{mg} / 0.1 \mathrm{~mL} 100 \mathrm{mg} / \mathrm{mL}$ stock solution) and $0.5 \mu \mathrm{g}$ mitomycin C (MMC; $\mathrm{C}_{15} \mathrm{H}_{18} \mathrm{~N}_{4} \mathrm{O}_{5}$, lot No. 237AEL, Bristol Myers Squibb, São Paulo, Brazil) for $25 \mathrm{~min}$ at $37^{\circ} \mathrm{C}$ and diluted in $\mathrm{M} 9$ buffer for the assays. A negative control $(100 \mu \mathrm{L}$ sterile distilled water) and a positive control $(0.5 \mu \mathrm{g} \mathrm{MMC})$ were also included.

To assess the anticytotoxic activity of DFE, we inoculated LB plates with $0.1-\mathrm{mL}$ aliquots of the dilutions in M9 buffer, incubated them for $24 \mathrm{~h}$ at $37^{\circ} \mathrm{C}$, and counted the total number of colonies. For assessment of the antigenotoxic activity of DFE, $0.1 \mathrm{~mL}$ strain WP2s $(\lambda)$ diluted in M9 buffer was added to $0.3 \mathrm{~mL}$ strain RJF013 and $2.5 \mathrm{~mL}$ top agar $(0.6 \%$ agar, lot No. 5294419, Difco; $0.5 \% \mathrm{NaCl}$, lot No. 87642, Vetec). This mixture was poured into $\mathrm{LB}_{(1 / 2)(\text { maltamp) }}$ plates and incubated for $24 \mathrm{~h}$ at $37^{\circ} \mathrm{C}$, and the number of plaques was counted.

\section{Mouse bone marrow micronucleus test}

\section{Animals}

This study was approved by the human and animal research ethics committee of the Universidade Federal de Goiás (CEPMHA/HC/UFG No. 044/09). Healthy, young, male adult (8-12 weeks) outbred mice (Mus musculus, Swiss Webster), weighing 25-30 g and obtained 
from the central animal house of the Universidade Federal de Goiás were randomly allocated into treatment groups. All animals were brought to the laboratory 5 days before the experiments and housed in plastic cages $(40 \times 30 \times 16 \mathrm{~cm})$ at $24 \pm 2^{\circ} \mathrm{C}$ and $55 \pm 10 \%$ humidity, with a light-dark natural cycle of $12 \mathrm{~h}$. Food (appropriate commercial rodent diet Labina, Ecibra Ltda., Santo Amaro, Brazil) and water were given ad libitum.

\section{Experimental procedure}

The experiments were performed according the procedure of von Ledebur and Schmid (1973). For each treatment, groups of 5 animals were orally treated with 3 doses of DFE (100, 200, and $300 \mathrm{mg} / \mathrm{kg}$ ) and simultaneously co-treated with MMC (4 mg/kg ip). A positive control group (4 mg/kg ip MMC, lot No. 237AEL, Bristol Myers Squibb) and a negative control group (sterile distilled water) were also included. The animals were killed via cervical dislocation 24 or $48 \mathrm{~h}$ after the administration of DFE, and their bone marrow cells were flushed from both femurs in fetal calf serum (FCS, lot No. 30721063, Laborclin, Campinas, Brazil). After centrifugation at $300 \mathrm{x} g$ for 5 $\mathrm{min}$, the bone marrow cells were smeared onto glass slides, coded for blind analysis, air-dried, and fixed with absolute methanol $\left(\mathrm{CH}_{4} \mathrm{O}\right.$, lot No. 55026, Synth, Diadema, Brazil) for 5 min at room temperature. The smears were stained with Giemsa (lot No. 1081, Doles, Goiânia, Brazil), dibasic sodium phosphate $\left(\mathrm{Na}_{2} \mathrm{HPO}_{4} 12 \mathrm{H}_{2} \mathrm{O}\right.$, lot No. 982162 , Vetec), and monobasic sodium phosphate $\left(\mathrm{NaH}_{2} \mathrm{PO}_{4} \mathrm{H}_{2} \mathrm{O}\right.$, lot No. 983831 , Vetec) to detect micronucleated polychromatic erythrocytes (MNPCEs). Three slides were prepared for each animal, and a minimum of 2000 polychromatic erythrocytes (PCEs) were counted to determine the frequency of MNPCEs. The anticytotoxic activity was evaluated using the PCE and normochromatic erythrocyte (NCE) ratio (PCE/NCE). The slides were analyzed with microscopy (Olympus BH-2 10 x 100, Tokyo, Japan).

\section{Statistical analysis}

The results of the survival and antigenotoxicity assays using the SOS-Inductest were generated with data from 4 independent experiments carried out in duplicate. All data obtained from the test plates and positive control plates (anticytotoxicity assay) as well as the number of plaques obtained from these plates were expressed as means \pm SD. These results were evaluated using analysis of variance and Tukey's posthoc test to compare the differences among the means. P values of $<0.05$ were considered significant.

To analyze the antimutagenic activity of DFE using the mouse bone marrow micronucleus test, we compared the frequencies of MNPCEs in the treated groups with the results obtained for the positive control groups using one-way analysis of variance. P values of $<0.05$ were considered significant. To assess the anticytotoxic activity of DFE, we compared the PCE/NCE ratios obtained at different concentrations with those of the positive controls using the chi-square test. $\mathrm{P}$ values of $<0.05$ were considered significant.

\section{RESULTS}

\section{SOS-Inductest}

Assessing the anticytotoxic activity of DFE, we detected an increase in the number of sur- 
vivors at all doses with co-treatment with MMC compared with that in positive control (Table 1).

The maximum increase in the number of survivors occurred with $2 \mathrm{mg}$ DFE, whereas the lowest occurred with $10 \mathrm{mg}$ DFE. At doses of $0.5,1$, and $5 \mathrm{mg}$, we also observed an increase in number of survivors $(\mathrm{P}<0.05)$. Therefore, DFE attenuated the cytotoxic effects of MMC.

On assessing the antigenotoxic activity of DFE, we observed a decrease in $\lambda$ prophage induction at all doses tested compared with that in the positive control $(\mathrm{P}<0.05$; see Table 1). The greatest decrease in $\lambda$ prophage induction occurred at a dose of $2 \mathrm{mg}$ DFE $(\mathrm{P}<0.05)$. Therefore, DFE also attenuated the genotoxic effects of MMC at all tested concentrations.

Table 1. Survival fraction (SF) and standard deviation (SD) of number of Escherichia coli WP2s $(\lambda)$ colonies, infective centers (IC) and SD of RJF013 E. coli cultures formed after treatment with different doses of DFE co-treated with MMC.

\begin{tabular}{lcc}
\hline Treatment & SF \pm SD (survival) & IC \pm SD (induction) \\
\hline Positive control (MMC) & $9.35 \times 106 \pm 0.76 \times 106^{\mathrm{b}}$ & $2.04 \times 107 \pm 0.17 \times 107^{\mathrm{b}}$ \\
$0.5 \mathrm{mg}$ DFE + MMC & $5.76 \times 107 \pm 1.49 \times 107^{\mathrm{a}}$ & $1.10 \times 107 \pm 0.08 \times 107^{\mathrm{a}}$ \\
$1 \mathrm{mg}$ DFE + MMC & $6.02 \times 107 \pm 0.70 \times 107^{\mathrm{a}}$ & $7.91 \times 106 \pm 0.75 \times 106^{\mathrm{a}}$ \\
$2 \mathrm{mg}$ DFE + MMC & $6.61 \times 107 \pm 1.11 \times 107^{\mathrm{a}}$ & $7.66 \times 106 \pm 0.99 \times 106^{\mathrm{a}}$ \\
$5 \mathrm{mg}$ DFE + MMC & $4.78 \times 107 \pm 1.06 \times 107^{\mathrm{a}}$ & $8.40 \times 106 \pm 1.68 \times 106^{\mathrm{a}}$ \\
$10 \mathrm{mg}$ DFE + MMC & $1.44 \times 107 \pm 0.31 \times 107^{\mathrm{b}}$ & $1.29 \times 106 \pm 0.20 \times 106^{\mathrm{a}}$ \\
\hline Negative control $\left(\mathrm{H}_{2} \mathrm{O}\right)$ & $2.02 \times 108 \pm 0.26 \times 108^{\mathrm{a}}$ &
\end{tabular}

All results were compared to their respective positive control. aSignificant difference compared to the positive control $(\mathrm{P}<0.05)$. ${ }^{b}$ Non significant difference compared to the positive control $(\mathrm{P}>0.05)$. DFE $=$ Duguetia furfuracea lyophilized leaf extract; $\mathrm{MMC}=0.5 \mu \mathrm{g}$ mitomycin $\mathrm{C}$.

\section{Mouse bone marrow micronucleus test}

The results indicated that simultaneous treatment with DFE and MMC reduced the number of MNPCEs compared with that in the positive control group $(\mathrm{P}<0.05$; Table 2$)$.

Thus, DFE showed antigenotoxic activity at all doses tested at 24 and $48 \mathrm{~h}$. Simultaneous treatment with DFE and MMC increased the PCE/NCE ratio $24 \mathrm{~h}$ after administration compared to that in the positive control group ( $\mathrm{P}<0.05$; see Table 2$)$. Therefore, simultaneous treatment with DFE and MMC resulted in anticytotoxic action at all doses tested at 24 and $48 \mathrm{~h}(\mathrm{P}<0.05)$.

Table 2. MNPCE frequencies and PCE/NCE ratio after treating the animals with different doses of DFE and times.

\begin{tabular}{|c|c|c|c|c|c|}
\hline Treatment & Time (h) & $\begin{array}{l}\text { Individual data } \\
\text { (MNPCE/2000 PCE) }\end{array}$ & Total MNPCE (No.) & $\begin{array}{l}\text { Mean } \pm \text { SD } \\
(\mathrm{MNPCE})\end{array}$ & $\begin{array}{l}\text { Mean } \pm \text { SD } \\
(\mathrm{PCE} / \mathrm{NCE})\end{array}$ \\
\hline Negative control $\left(\mathrm{H}_{2} \mathrm{O}\right)$ & 24 & $3,5,3,4,4$ & 19 & $3.8 \pm 0.84$ & $1.06 \pm 0.06$ \\
\hline Positive control (MMC) & 24 & $29,40,36,38,35$ & 178 & $35.6 \pm 4.16^{\mathrm{b}}$ & $0.46 \pm 0.01^{\mathrm{b}}$ \\
\hline $100 \mathrm{mg} / \mathrm{kg}$ DFE + MMC & 24 & $19,15,17,20,21$ & 92 & $18.4 \pm 2.4^{\mathrm{a}}$ & $0.58 \pm 0.05^{\mathrm{a}}$ \\
\hline $200 \mathrm{mg} / \mathrm{kg} \mathrm{DFE}+\mathrm{MMC}$ & 24 & $20,17,16,18,18$ & 89 & $17.8 \pm 1.48^{\mathrm{a}}$ & $0.63 \pm 0.02^{\mathrm{a}}$ \\
\hline $300 \mathrm{mg} / \mathrm{kg} \mathrm{DFE}+\mathrm{MMC}$ & 24 & $24,17,19,20,26$ & 106 & $21.2 \pm 3.7^{\mathrm{a}}$ & $0.53 \pm 0.03^{\mathrm{a}}$ \\
\hline Positive control (MMC) & 48 & $9,11,12,9,7$ & 48 & $9.6 \pm 1.95^{b}$ & $0.26 \pm 0.006^{\mathrm{b}}$ \\
\hline $100 \mathrm{mg} / \mathrm{kg}$ DFE + MMC & 48 & $5,3,4,6,6$ & 24 & $4.8 \pm 1.3^{\mathrm{a}}$ & $0.38 \pm 0.03^{\mathrm{a}}$ \\
\hline $200 \mathrm{mg} / \mathrm{kg}$ DFE + MMC & 48 & $3,4,5,3,5$ & 20 & $4.0 \pm 1.0^{\mathrm{a}}$ & $0.4 \pm 0.03^{\mathrm{a}}$ \\
\hline $300 \mathrm{mg} / \mathrm{kg}$ DFE + MMC & 48 & $7,7,4,5,6$ & 29 & $5.8 \pm 1.3^{\mathrm{a}}$ & $0.35 \pm 0.01^{\mathrm{a}}$ \\
\hline
\end{tabular}

\section{DISCUSSION}

The composition of natural extracts that apparently exhibit only beneficial properties 
may include chemical components with mutagenic, genotoxic, teratogenic, or carcinogenic actions. If a genotoxic agent is present, it can interact with DNA molecules, causing genetic damage in regions of fundamental importance to cell cycle control and apoptosis and giving rise to a neoplastic process (Alves dos Santos et al., 2008). In contrast, chemicals present in plants may also act as anticarcinogens or antimutagens by blocking ultimate carcinogen electrophiles in a nucleophilic chemical reaction to form innocuous products. A continuous input of these compounds could serve as a buffer against DNA damage (Duhan et al., 2011).

Recently, cancer chemoprevention has become a promising alternative for controlling cancer now that a large number of modulating factors including antimutagens and anticarcinogens have been widely studied to assess their capability to suppress or prevent carcinogenesis. Plants and their products represent one of the main sources of compounds with chemopreventive potential and, indeed, several secondary plant metabolites have demonstrated chemopreventive activity (Mezzoug et al., 2007).

In the present work, we evaluated the antigenotoxic and anticytotoxic potential of DFE using the SOS-Inductest (Moreau et al., 1976) and the mouse bone marrow micronucleus assay (Heddle, 1973). The SOS-Inductest is a short-term assay performed with E. coli lysogenic strains that evaluates the genotoxic action of compounds for quantitative evaluation of an SOS function. When bacteria are exposed to damaging DNA agents that inhibit DNA replication, prophages enter the lytic cycle as an expression of SOS induction (Moreau, 1981). The in vivo mouse bone marrow micronucleus test is a mutagenicity test system for the detection of agents that induce chromosome fragments (clastogenic effect) or aneuploidy (aneugenic effect) (Kirsch-Volders et al., 1997). Both tests are often used to study the antigenotoxic activity of a compound.

One of the best ways to minimize the effect of mutagens and carcinogens is to identify anticlastogens/antimutagens (substances that suppress or inhibit mutagenesis by acting directly on cell mechanism) and desmutagens (substances that partially or fully destroy or inactivate mutagens) in the diet and increase their consumption. Because nature has provided a rich variety of medicinal plants, they should be used as antimutagenic and anticarcinogenic food or drug additives (Sumanth and Chowdary, 2010).

In this study, the antimutagenic activity of DFE was evaluated by measuring its inhibitory effect on MMC-induced mutagenesis. The results obtained using the micronucleus test agreed with those of the SOS-Inductest. A relevant decrease in the induction of prophage $\lambda$ was detected using the SOS-Inductest at all doses of DFE co-administered with MMC compared to that in the positive control $(\mathrm{P}<0.05)$, demonstrating its antigenotoxic action. In the micronucleus test, the frequency of MNPCEs at all doses of DFE co-administered with MMC decreased compared with that in the positive control group $(\mathrm{P}<0.05)$ at 24 and $48 \mathrm{~h}$. These results indicated that DFE modulated the genotoxic action of MMC and therefore displayed antigenotoxic activity, which is corroborated by the findings of Coelho et al. (2011), who observed a modulatory effect of DFE against the genotoxic activity of urethane in Drosophila melanogaster.

The PCE/NCE ratio in the groups treated with DFE and MMC was increased compared to that in the positive control group at all doses tested at 24 and $48 \mathrm{~h}$, indicating a protective effect against the cytotoxic action of MMC in mouse bone marrow. The results obtained using the SOS-Inductest demonstrated that DFE attenuated the cytotoxic action of low doses of MMC. However, at a dose of $10 \mathrm{mg}$ DFE, the increased number of survivors was not significant, possibly owing to the cytotoxic action of higher doses $(5$ and $10 \mathrm{mg})$ of DFE against E. coli demonstrated in our previous studies (Silva et al., 2012). 
The results obtained in both assays showed that the maximum protective effect of DFE against the cytotoxic and genotoxic effects of MMC occurred at intermediate doses (2 $\mathrm{mg}$ in the SOS-Inductest and $200 \mathrm{mg} / \mathrm{kg}$ in the micronucleus test), leading to the conclusion that its antigenotoxic and anticytotoxic actions are dose specific.

Phytochemical analysis of the aerial parts of Duguetia furfuracea showed the presence of sesquiterpenes (Carollo et al., 2005), flavonoids, and several alkaloids (Carollo et al., 2006a,b). Recent studies have demonstrated that the alkaloid extract and 5 alkaloids isolated from Duguetia furfuracea subterranean stem bark have cytotoxic, antitumoral, trypanocidal, and leishmanicidal activities (Da Silva et al., 2009). Literature data have shown that sesquiterpenes are potential anticancer agents (Fraga, 2006). Flavonoids are commonly categorized as anti-inflammatory, anticarcinogenic, diuretic, antimicrobial, antiviral, and antioxidant compounds (Hu et al., 2011; Miller et al., 2012). The presence of certain substances in plants, including flavonoids and terpenoids, may protect cells against DNA damage (Silva et al., 2006). Thus, the protective effect of DFE against MMC genotoxicity and cytotoxicity can be attributed at least partially to the chemopreventive effects of sesquiterpenes and flavonoids present in Duguetia furfuracea.

\section{ACKNOWLEDGMENTS}

Research supported by Fundação de Amparo à Pesquisa do Estado de Goiás, Fundação de Apoio à Pesquisa, Conselho Nacional de Desenvolvimento Científico e Tecnológico, and Universidade Federal de Goiás.

\section{REFERENCES}

Alves dos Santos R, Cabral TR, Cabral IR, Antunes LM, et al. (2008). Genotoxic effect of Physalis angulata L. (Solanaceae) extract on human lymphocytes treated in vitro. Biocell 32: 195-200.

Bouhlel I, Mansour HB, Limem I, Sghaier MB, et al. (2007). Screening of antimutagenicity via antioxidant activity in different extracts from the leaves of Acacia salicina from the center of Tunisia. Environ. Toxicol. Pharmacol. 23: 56-63.

Cardoso CR, de Syllos Colus IM, Bernardi CC, Sannomiya M, et al. (2006). Mutagenic activity promoted by amentoflavone and methanolic extract of Byrsonima crassa Niedenzu. Toxicology 225: 55-63.

Carollo CA, Hellmann AR and Siqueira JM (2005). Sesquiterpenoids from the essential oil from leaves of Duguetia furfuracea (Annonaceae). Biochem. Syst. Ecol. 33: 647-649.

Carollo CA, Hellmann-Carollo AR, Siqueira JM and Albuquerque S (2006a). Alkaloids and a flavonoid from aerial parts (leaves and twigs) of Duguetia furfuracea - Annonaceae. J. Chil. Chem. Soc. 51: 837-841.

Carollo CA, de Siqueira JM, Garcez WS, Diniz R, et al. (2006b). N-nitrosoanonaine and N-nitrosoxylopine, aporphine alkaloids from Duguetia furfuracea. J. Nat. Prod. 69: 1222-1224.

Cherdshewasart W, Sutjit W, Pulcharoen K and Chulasiri M (2009). The mutagenic and antimutagenic effects of the traditional phytoestrogen-rich herbs, Pueraria mirifica and Pueraria lobata. Braz. J. Med. Biol. Res. 42: 816-823.

Choi EM and Hwang JK (2003). Investigations of anti-inflammatory and antinociceptive activities of Piper cubeba, Physalis angulata and Rosa hybrida. J. Ethnopharmacol. 89: 171-175.

Coelho LS, Felicio LP, Miranda CT, da Silva EM, et al. (2011). Modulatory effects of Duguetia furfuracea (A. St. Hil) Benth. and Hook. f. in Drosophila melanogaster somatic and germinative cells. Genet. Mol. Res. 10: 75-85.

da Fonseca CA, Leal J, Costa SS and Leitao AC (1994). Genotoxic and mutagenic effects of guarana (Paullinia cupana) in prokaryotic organisms. Mutat. Res. 321: 165-173.

Da Silva DB, Tulli EC, Militao GC, Costa-Lotufo LV, et al. (2009). The antitumoral, trypanocidal and antileishmanial activities of extract and alkaloids isolated from Duguetia furfuracea. Phytomedicine 16: 1059-1063.

de Mesquita ML, Grellier P, Mambu L, de Paula JE, et al. (2007). In vitro antiplasmodial activity of Brazilian Cerrado plants used as traditional remedies. J. Ethnopharmacol. 110: 165-170. 
Déciga-Campos M, Rivero-Cruz I, Arriaga-Alba M, Castaneda-Corral G, et al. (2007). Acute toxicity and mutagenic activity of Mexican plants used in traditional medicine. J. Ethnopharmacol. 110: 334-342.

Duhan JS, Bhardwaj M and Surekha (2011). Free radical-scavenging and antimutagenic potential of acetone, chloroform and methanol extracts of fruits of Argemone mexicana. Afr. J. Biotechnol. 10: 8654-8661.

Fischer DC, de Amorim Gualda NC, Bachiega D, Carvalho CS, et al. (2004). In vitro screening for antiplasmodial activity of isoquinoline alkaloids from Brazilian plant species. Acta Trop. 92: 261-266.

Fraga BM (2006). Natural sesquiterpenoids. Nat. Prod. Rep. 23: 943-972.

Ghazali AR, Abdullah R, Ramli N, Rajab NF, et al. (2011). Mutagenic and antimutagenic activities of Mitragyna speciosa Korth extract using Ames test. J. Med. Plants Res. 5: 1345-1348.

Heddle JA (1973). A rapid in vivo test for chromosomal damage. Mutat. Res. 18: 187-190.

Hu X, Ji J, Wang M, Wu JW, et al. (2011). New isoprenylated flavonoids and adipogenesis-promoting constituents from Morus notabilis. Bioorg. Med. Chem. Lett. 21: 4441-4446.

Kilani S, Ben AR, Bouhlel I, Abdelwahed A, et al. (2005). Investigation of extracts from (Tunisian) Cyperus rotundus as antimutagens and radical scavengers. Environ. Toxicol. Pharmacol. 20: 478-484.

Kirsch-Volders M, Elhajouji A, Cundari E and Van HP (1997). The in vitro micronucleus test: a multi-endpoint assay to detect simultaneously mitotic delay, apoptosis, chromosome breakage, chromosome loss and non-disjunction. Mutat. Res. 392: 19-30.

Mezzoug N, Elhadri A, Dallouh A, Amkiss S, et al. (2007). Investigation of the mutagenic and antimutagenic effects of Origanum compactum essential oil and some of its constituents. Mutat. Res. 629: 100-110.

Miller BJ, Pieterse T, Marais C and Bezuidenhoudt BCB (2012). Ring-closing metathesis as a new methodology for the synthesis of monomeric flavonoids and neoflavonoids. Tetrahedron Lett. 53: 4708-4710.

Mohd-Fuat AR, Kofi EA and Allan GG (2007). Mutagenic and cytotoxic properties of three herbal plants from Southeast Asia. Trop. Biomed. 24: 49-59.

Moreau PL (1981). Mécanismes de la mutagénèse et de l'induction lysogénique. Principe des tests bactériens pour la détection des cancérogènes et antitumoraux potentiels. Sci. Techn. Animaux. Lab. 6: 267-277.

Moreau P, Bailone A and Devoret R (1976). Prophage lambda induction of Escherichia coli K12 envA uvrB: a highly sensitive test for potential carcinogens. Proc. Natl. Acad. Sci. U. S. A. 73: 3700-3704.

Park KY, Jung GO, Lee KT, Choi J, et al. (2004). Antimutagenic activity of flavonoids from the heartwood of Rhus verniciflua. J. Ethnopharmacol. 90: 73-79.

Resende FA, Alves JM, Munari CC, Senedese JM, et al. (2007). Inhibition of doxorubicin-induced mutagenicity by Baccharis dracunculifolia. Mutat. Res. 634: 112-118.

Rodrigues VEG and Carvalho DA (2001). Levantamento etnobotânico de plantas medicinais no domínio do cerrado na região do Alto Rio Grande - Minas Gerais. Cienc. Agrotec. 25: 102-123.

Silberbauer-Gottsberger I (1981/1982). O cerrado como potencial de plantas medicinais e tóxicas. Oréades 14/15: 15-30.

Silva CJ, Ferreira HD, Ferri PH, Nunes WB, et al. (2006). Ausência de atividade mutagênica de Guazuma ulmifolia Lamb. (mutamba) em células somáticas de Drosophila melanogaster. Rev. Biol. Neotrop. 3: 163-168.

Silva CR, Vieira PM, Santos SC and Chen-Chen L (2012). Assessment of Duguetia furfuracea genotoxic and cytotoxic activity in bacteria and mice. An. Acad. Bras. Cienc. 84: 149-156.

Sumanth M and Chowdary GN (2010). Antimutagenic activity of aqueous extract of Momordica charantia. Int. J. Biotechnol. Mol. Biol. Res. 1: 42-46.

Toledo MRS, Peres MTLP, Vieira MC, Bazzano TSC, et al. (2006). Fitotoxicidade do extrato aquoso de Duguetia furfuraceae (St. Hill) B et H em ratas (Rattus norvegicus). RBPM 8: 218-222.

von Ledebur M and Schmid W (1973). The micronucleus test. Methodological aspects. Mutat. Res. 19: 109-117. 